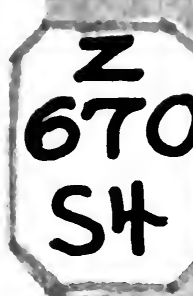

UC-NRLF

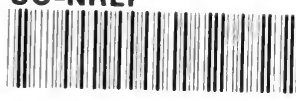

\$B 9中? ?

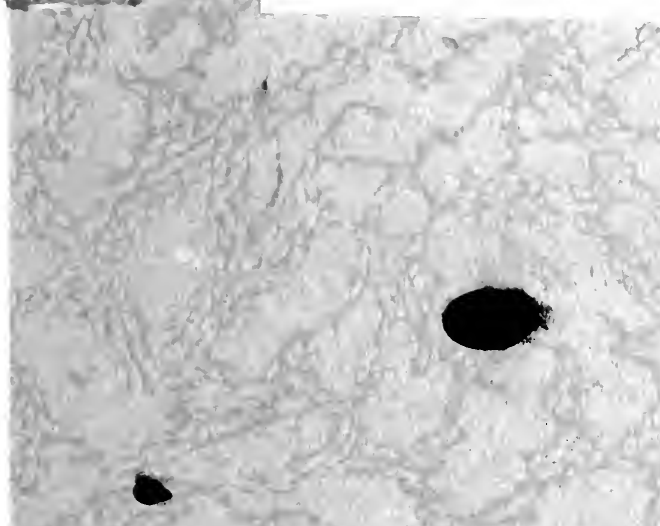

$\infty 0$

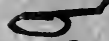

10

$\infty$

( 


\title{
MANUAL FOR INSTITUTION LIBRARIES
}

\author{
COMPILED BY \\ CARRIE E. SCOTT \\ Ass's State Organizer, Public Library Commission of Indiana \\ ASSISTED BY
}

The American Library Association Committee on Library Work in Hospitals and in Charitable and Correctional Institutions

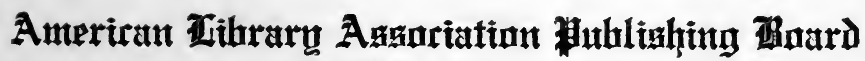
CHICAGO 
Digitized by the Internet Archive in 2007 with funding from Microsoft Corporation 


\title{
MANUAL FOR INSTITUTION LIBRARIES
}

\author{
COMPILED BY \\ CARRIE E. SCOTT
}

Ass't State Organizer, Public Library Commission of Indiana

ASSISTED BY

The American Library Association Committee on Library Work in Hospitals and in Charitable and Correctional Institutions

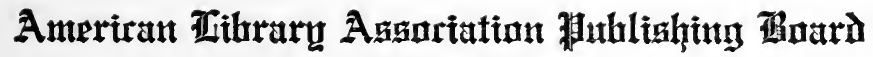
CHICAGO

1916 


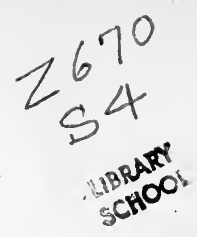

\section{COMMITTEE ON LIBRARY WORK IN HOS- PITALS AND CHARITABLE AND COR- RECTIONAL INSTITUTIONS}

Miriam E. Carey, Supervisor of Institution Libraries, Minne- . sota State Board of Control, St. Paul.

Julia A. Robinson, Secretary Iowa Library Commission, Des Moines.

E. Kathleen Jones, Librarian McLean Hospital, Waverley, Mass.

Florence R. Curtis, Instructor University of Illinois Library School, Urbana.

Nellie Williams, Librarian for State Institutions, Public Library Commission, Lincoln, Neb.

Mary E. Eastwood, Chief Book Selection Section, New York State Library, Albany.

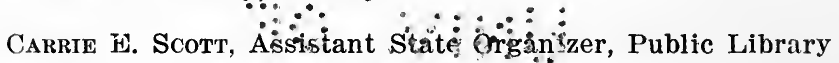
Commission of Indiana, Indianapolis.

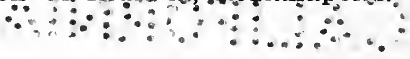




\section{INTRODUCTION}

The library in a state institution is confronted by a threefold problem. It is concerned with getting suitable books, finding and equipping a place to keep them, and carrying on the library so as to make it effective.

It is not very difficult to get a collection of books for an institution, but it is often a hard matter to find a suitable room for library purposes. Moreover, it is not enough to have the room and the books, there must be a person to act as librarian.

Notwithstanding these obstacles, there are a number of institutions in the United States that have succeeded in getting all three of these requisites and their experience is unanimous on two points. First, they are agreed that there should be a central library from which books could be issued singly or in quantities and to which the inmates could go in person without disturbing the routine of the place. Second, they believe that the library must be recognized as a distinct department and have a suitable officer in charge who will devote at least half his time to its management.

The questions which must be answered by an institution librarian may be grouped as follows:

1. What books shall I select?

2. How shall I arrange them?

3. How shall I keep track of them?

4. How shall I get them to the readers?

5. How shall I keep them in good condition?

The Manual which is herewith presented aims to provide a guide for librarians in hospitals, prisons, reformatories, schools for the deaf, blind, feeble-minded, and children who are wards of the state.

Under the headings of Book selection, Classification and Shelf arrangement, Records, Circulation, Mending and Bind- 
ing, this Manual will present the standard methods of library service adapted to conditions in institutions.

Standard methods are those which have been in use in the majority of libraries long enough to have been tried out and found worth while. These methods have been expressed in printed form under the auspices of the American Library Association and the U. S. Department of Education. They are therefore available for study to all who are investigating these matters. 


\section{MANUAL FOR INSTITUTION LIBRARIES}

\section{BOOK SELECTION}

Who shall select the books?-The most competent person in the institution by reason of education, training and wide reading should select the books for the library. These qualities should be united in the librarian, but if they are not, and the librarian neither knows nor loves books, the state library commission or library supervisor should be consulted. Failing these, advice should be asked trom the nearest large public library.

Helps in selection-As book selection for institution 11 braries should be based on the class of inmates and the functions of the institution there are no lists which furnish authoritative guidance.

The following are the lists used by public libraries. These may serve as a basis for selection, but the books must be thoroughly examined, read and criticized from the standpoint of each institution before they are finally accepted:

Best books, published annually by New York State L1brary, Albany. 10 cents.

A. L. A. Booklist, published by the American Library Association, 78 East Washington Street, Chicago. 10 nos. a year. $\$ 1.00$.

Wisconsin Bulletin. Monthly, published by Wisconsin Free Library Commission, Madison. Per year, $\$ 1.00$.

New Jersey Bulletin, published by New Jersey Library Commission, Trenton. Free.

The above lists are for books recently published. When standard books are wanted the two catalogs published by the American Library Association in 1904 and 1911 are the best guides as to editions and prices. 
The American Library Association also publishes several lists of books in foreign languages and $A$ thousand books for the hospital library, each at 25 cents.

The New York State library, Albany, has issued this year a List of books for prison libraries, part I, compiled by the book selection section of the New York State Library. It contains a list of five hundred good stories, also a list of stories of special interest to women. 10 cents.

How often should books be bought?-Books should be bought at least annually, but as new books are the best stimulus of interest, the more frequent the purchase the better. As most institutions have their own printeries it is not difficult to keep a printed catalog up-to-date or to provide lists of new books for distribution when there is no catalogue.

\section{BOOK FUND}

Unless there is a definite appropriation for books set aside when the other institution departments are provided for, the library has great difficulty in getting funds for upkeep and progress. Once a library has "run down" it is a serious matter to bring it back to par. There is such constant use of every institution library that the ordinary wear-and-tear of service will reduce the quota of sound and perfect books so greatly that it is always necessary to have funds in order to prevent deterioration.

The annual appropriation should be sufficient to maintain the library on a par with the other departments of the institution. Whatever the fund is, it will never be too large for all possible needs.

Every institution should aim to have a working library of at least 1000 volumes, and its ultimate size should be governed by the character of the institution-whether the population changes rapidly or not, whether the majority of the inmates are well-educated or illiterate, the proportion of foreigners not reading English, and the amount of space available for library purposes.

Once the stock on hand is adequate, the annual expenditure of $\$ 250$ for books, binding and periodicals is adequate in most institutions. "Get all you can," however, is 
the advice offered by some authorities. One prison in the west with a population of 500 , spends $\$ 500$ for books and magazines.

The size of the institution is not the governing factor. You want as good a library for 50 inmates as for 500 . You want a better class of books for the educated than the illiterate.

\section{EDITIONS}

As an institution library is for use, the editions purchased should be serviceable. Good paper, print and illustrations are necessary for use, but as a rule the inexpensive editions are most satisfactory because they can be destroyed when soiled and replaced by clean copies. This is more sanitary than rebinding and is not much more expensive.

\section{NON-FICTION}

The first purchase for every institution library should include some reference books, such as a dictionary, an atlas or gazetteer, and an encyclopædia. The great divisions of literature should all be represented, the proportion of each to be governed by the character and purpose of the institution.

\section{FICTION}

Libraries in hospitals, being chiefly recreational, should have a large proportion of fiction, probably 75 per cent. The first requisite is that the books shall be interesting, attractive, and easily read. Literary quality is of minor importance.

Fiction for prisons and reform schools should be censored carefully. Nothing should be accepted which represents vice attractively, contains sensual suggestions, or deals with crime and punishment.

A prisoner has a right to an environment which will give him a chance to improve. The exceptional man among the convicts is the one whose needs should govern the selection of books for the library. Students among the 
men may well be consulted every time books are bought, that such men may always find at hand the books they need. It is not unusual for convicts to take correspondence courses. A prison which is so poorly equipped that the students within the walls are obliged to buy with their own funds the books they need has no reason to be proud of its system.

Let the prison library not only meet the recognized needs of the men, but inspire them to further efforts. The reading habit once firmly fixed is one of the best safeguards for any man.

\section{CHILDREN'S BOOKS}

Children in institutions should have the same sort of books that other children enjoy elsewhere, such as fairy tales, picture books, stories and other works adapted to children. No effort should be spared to cultivate a taste for good books and familiarity with library customs.

If expensive books are bought anywhere, let it be in the children's libraries. There is more than mere amusement in a beautiful book.

\section{ADMINISTRATION}

The librarian-No library will run itself. It is necessary to have an organized staff for this purpose. The most competent person for the position may be too much occupied to do more than manage the department, but even so it is better to have the enthusiastic interest of the right sort of director than the full time of someone without qualifications for the work. It is not possible to get full value from a library without a librarian definitely appointed to the work and held responsible for it. Every institution roster should specify some officer as librarian. Technical training is very desirable but not as essential as familiarity with books and an appreciation of their value.

Some institutions combine the positions of secretary and librarian; others teacher and librarian. These are usually 
satisfactory as both positions require education. To combine the operation of the telephone or the management of a cellhouse, or attendance on a hospital ward with library service is not so sure of good results.

Teachers make excellent librarians in schools. They should be recognized as librarians and be allowed at least half time for this department. As the library grows it will require more and more of the librarian's time to keep up the mere mechanical part of the work. This is seldom thought of and more than one faithful teacherlibrarian has sacrificed most of his leisure time, feeling helpless to explain the actual conditions.

In order to conserve the librarian's strength and enthusiasm, he should have a staff of assistants which he should train to carry on the daily routine of the library, such as charging and discharging books, returning them to the shelves, keeping the shelves in order, mending the books. It should be remembered that all handling of books is more or less educative. To work in a library is a good thing for any pupil. He might be allowed credit for it but should not be paid in money. If the librarian-teacher has a staff of this character, there will always be someone in the school who has had enough training to keep the library running during a temporary absence of the chief.

Technical training-Why should an institution librarian be trained?

Because he needs to know what the best standards are in order to discriminate between suitable and unfit books for each institution. He must be familiar with the meth. ods which have been successful in order to lose no time in experimenting. He must know how to get the most for his money-when and where to buy at the best advantage, and what to discard and reject. He must be able to cope with book agents and to lead would-be donors into paths profitable to the library. He needs to know the technical side of library work in order to conserve his own time and that of the library patrons. He must realize the possibilities of books before he can get results from them. 
He can have no real enthusiasm until he has studied both the possibilities of books and the needs of the institution. He will not have to create a desire to read on the part of most of the residents, for the period of enforced leisure in each day does that automatically. But he will have occasion to make a study of all phases of the question in order to adapt himself to local conditions and get the right books to the right people.

\section{FURNITURE AND FITTINGS}

Few institutions about to build include a room for the library in the plans and specifications. When, therefore, it becomes necessary to arrange for space for this department, all sorts of makeshifts are resorted to before the matter is settled. The ideal place for a library is in a separate building not used for library purposes alone but shared by the school or industrial and recreational departments. There are few such buildings as yet but there will be more, for there is a demand for a quiet "place to go to," on the part of the better class of inmates who miss the privacy of homelife and long for some retreat from the confusion and discontent which are more or less inevitable. Superintendents are beginning to recognize the value of the library as a remedial agent not only in its books but in its environment. Let the library be as homelike as possible, with curtained windows, comfortable chairs, several tables at which four or five readers can sit at once, preferably round tables, good lights, pictures, plants, casts, and other embellishments. An open fireplace and a good rug are most desirable.

Shelving-The books should be shelved in wooden cases made by the institution carpenter and the wallspace around the room should be shelved first. Cases should be low enough to admit of reaching the topshelf without difficulty. The standard height is 7 feet 2 inches, which allows for a 4 inch cornice, 6 inch base, 7 spaces 10 inches in the clear and 6 shelves 1 inch in thickness. The shelves should be adjustable. Walls back of cases may be painted to match the woodwork. 
Open shelves vs. locked cases-Shelves should be open except in those places in which the library is not an organized department but "runs itself." The moral effect of open shelves is recognized by some experienced institution librarians who have found that the inmates respond to trust. Open shelves do not often cause the loss of books.

Much of the furniture used in an institution library can be made on the premises but a patent card cabinet, although expensive, is the best of economy in the end. The trays must be made to fit cards exactly and to be interchangeable in the cabinet; a local carpenter will not be able to do this satisfactorily, or if he is, it will cost more than the patent one. Cases containing 2, 4, or 6 trays, ranging in price from $\$ 5$ to $\$ 12$ may be obtained from a library supply house.

Periodical case-A case may be built into the wall for current periodicals, consisting of pigeonholes 4 inches high, 8 inches deep and 10 inches long, above a ledge 36 inches from the floor. Below the ledge the shelves may be divided to accommodate the larger magazines. This case may be used for recent unbound files and a sloping rack be provided for current numbers. The rack may be built into or against the wall, and may consist of steps 6 inches high and $2 \frac{1}{2}$ inches deep, with slats 3 inches wide across the face, the tops of the slats on a level with the steps, allowing a space of 2 inches between. (See Stearns, Essentials in library administration, p. 85.)

Mending and binding-Many institutions contain binderies and nearly all could add a simple equipment sufficient to re-sew books. In industrial schools, bookbinding might well be taught as a trade. Many trained librarians at present have had courses in bookbinding and are prepared to direct this important part of the library work.

As soon as the sections or signatures of a book begin to loosen or wear, the book should be set aside for the bindery, if there is one in the institution, and should be 
re-sewed and put back in the same cover if possible, as the original publisher's cover is more attractive than a binder's cover. The book will wear two or three times as long.

If there is no institution bindery, sending the books away means their absence from the shelves a long time and the question must be decided as to what is worth rebinding and what shall be repaired only. It is the opinion of experienced workers that books of temporary interest, books undeserving a place in a good library, should not be rebound. They should be discarded as soon as they are worn and should not be replaced. Before they and other books reach the discard, however, there are many ways of prolonging their existence and for this purpose every librarian should be supplied with certain mending materials, a list of which will be found under Supplies. In hospitals for the insane the nearly worn-out books can be sent to the wards for destructive patients.

The following quotation from Essentials in library administration is full of suggestion:

"It is very important that the books of a library which need mending should be promptly and carefully repaired. Every book, when returned, should be looked over for loose leaves, tears, or marks, and nothing should be placed on shelves that needs the least attention.

"In putting in single leaves, or mending tears, thin onion-skin paper (which is transparent) should be used with flour paste. Loose signatures should be sewed in, using linen thread and a curved needle and fastening the ends very carefully. Never use glue or mucilage in replacing loose leaves or signatures, and use paste very sparingly, and only for tipping in single leaves and illustrations. Too much paste on the inner margin of the leaves makes it impossible for the binder to make secure stitching when the book comes to him."

A publication that will give many practical suggestions on the mending and care of books is published by the American Library Association. It is Mending and repair of books, compiled by Margaret Wright Brown. Third edition revised by Gertrude Stiles, supervisor of bindery, Cleveland public library. Price, paper, 15 cents. 
Periodicals-How many periodicals should an institution provide annually? The answer is, as many as it can afford. Periodicals have all the qualities that books have for meeting conditions of institution life besides being even more easily carried about. It would not be impossible to put a magazine into the hands of every inmate.

To keep periodicals circulating and prevent their piling up somewhere, is difficult to accomplish. In order to do it there must be some one person with a knack for organization backed by authority to give personal attention to this work. When done successfully it will bring the pleasantest of results that will more than repay for the time spent on the work. In addition to the chief, there must be someone to prepare the covers of new magazines for hard service by lining them with paper-muslin, cheesecloth, or manila paper or putting them in pamphlet binders. They should then be given out from the library in the same manner as books, but for shorter periods. The chief should decide which periodicals ought to be bound and duplicate copies of these should be provided. After these permanent files are set aside, the remainder of the magazines should be kept moving through the institution following a fixed plan so that even the most disturbed wards in large hospitals can always have magazines.

The following plan may prove suggestive to all institutions: At Mt. Pleasant, new magazines are sorted so that the men and women will receive the ones most interesting to them respectively, and each number is given a cover of stout manila paper. If there are two persons working together in the library, with plenty of time at their disposal, it is a good plan to put book-pockets and cards inside the covers, as the cards, being retained in the library, will always show where a given magazine is. But as this system takes more time than the needs of a hospital really demand, a substitute method is to paste on the cover of the magazine a slip of paper with the numbers or names of wards and cottages which are to receive it, and when the magazine is sent out the slip is checked ac- 
cordingly. By working out a scheme for the movement of the periodicals a certain guidance is given the circulation, which will follow the lines indicated by the slips on the covers. Every Saturday morning the attendants are required to bring to the library all the magazines in the wards. These are put into laundry baskets at one side and new magazines are issued in exchange. After library hours the returned magazines are sorted over; those that are in good condition are put into drawers by themselves to be issued the following week, and the worn numbers are collected for use in the back wards. In this way every ward in the hospital receives a certain quota of fresh periodicals every week-the newest issues, the best of the older ones, and the partly worn are all kept moving. It will occasionally happen that the same magazine will be received more than once, but in the long run all patients who wish to read will have a chance to see the ones they prefer.

Periodical checklist-It is necessary to keep a careful record of the magazines and periodicals for which the institution subscribes. This record is best kept on cards which are planned for this purpose. Cards similar to the samples below are made out for each periodical and filed in alphabetical order. When the publication comes, if it is a monthly, one check mark is placed in the proper month space. There is no special card form for weeklies. A monthly card can be well adapted by checking four or five times in the monthly space according to the number of issues in that month. Special cards are made out for the dailies. Unless the daily newspapers are to be bound, there is no need of keeping a checklist for them. 
Cards for Periodical Checklist.

Monthly

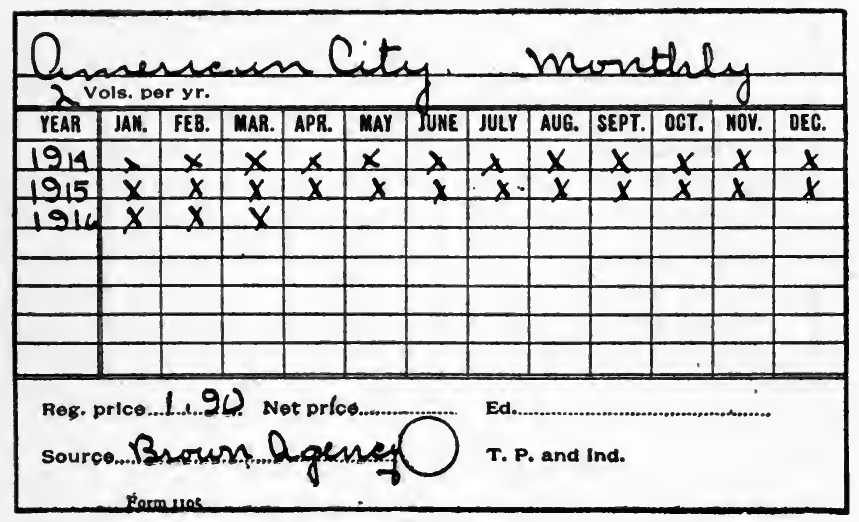

Daily

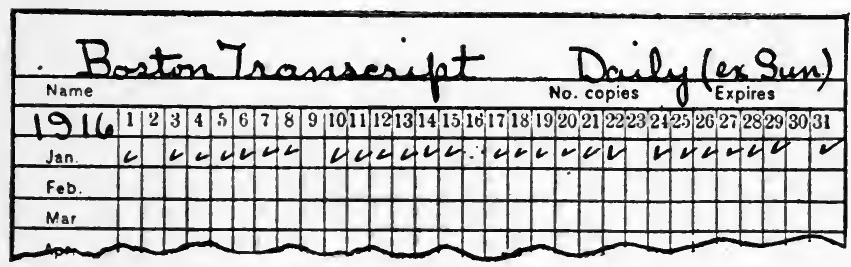




\section{Magazine Card}

No. 74.06 Name Smich

Barracks. C Cell 35 Range 6

NOTE: Place $(X)$ to left of Magazine you pref $\mathrm{r}$; but if you wish certain months, indicate your preference (/2iu the month space $\checkmark$ agazines may te hept TWO WEEKS.

Do not erase, any marks placed on your card by the Librarian. 1 hey are placed there for your benefit.

Ainsle's

$\begin{array}{lllllllllllll}1 & 2 & 3 & 4 & 5 & 6 & 7 & 8 & 9 & 10 & 11 & 14\end{array}$

$\begin{array}{llllllllllllllll}\text { American } & 1 & 2 & 3 & 4 & 5 & 6 & 7 & 8 & 9 & 10 & 11 & 1\end{array}$

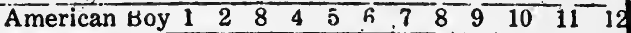

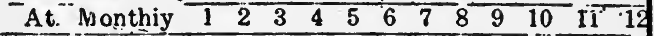

kaseball Mag. 1 $\begin{array}{lllllllllllllllllllllll}\text { Blue Book } & 1 & 2 & 3 & 4 & 5 & 6 & 7 & 8 & 9 & 10 & 11 & 12\end{array}$

\begin{tabular}{lll|lllllllllll}
\hline Century & & 2 & 4 & 5 & 6 & 7 & 8 & 9 & 10 & 11 & 12 \\
\hline
\end{tabular}

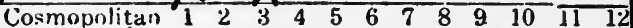

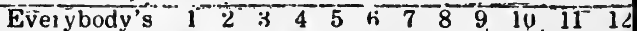

\begin{tabular}{|l|l|llllllllll}
\hline XHurper's & $\mathbf{2}$ & 2 & 4 & 5 & 6 & 7 & 8 & 9 & 10 & 11 & 12 \\
\hline
\end{tabular}

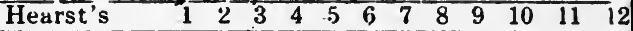

\begin{tabular}{llllllllllllll}
\hline Hunter & $\mathrm{T} \& \mathrm{~T}$ & 1 & 2 & 3 & 4 & 5 & 6 & 7 & 8 & 9 & 10 & 11 & 12
\end{tabular}

\begin{tabular}{llllllllllllll}
\hline Mcuride's & $\times$ & 2 & $\times$ & 4 & 5 & 6 & 7 & 8 & 9 & 10 & 11 & 12
\end{tabular}

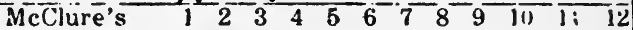

XMclean's $1 \times \times 44566789$ i1) 1112

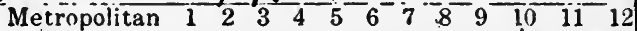

Munsey's $\quad 1-2-3-4-5-6-7-8-10-11^{-12}$

$\begin{array}{lllllllllllllll}\text { Nationa } & 1 & 2 & 3 & 4 & 5 & 6 & 7 & 8 & 9 & 10 & 11 & 12\end{array}$

XN. Am: Rev. XXX

Outing 1 2 $34^{-} 5^{-} 6^{-} 7^{-} 89^{-} 10 \begin{array}{lll}11 & 12\end{array}$

\begin{tabular}{llllllllllllll}
\hline Pearsion's & 1 & 2 & 3 & 4 & 5 & 6 & 7 & 7 & 4 & 1 & 11 & 12 \\
\hline
\end{tabular}

Pop. Mech. $1 \begin{array}{llllllllllll} & 2 & 3 & 4 & 5 & 6 & 7 & 8 & 9 & 10 & 11 & 12\end{array}$

-R. R.Man's I 2 - $3 \begin{array}{llllllllll} & 5 & 6 & 7 & 8 & 6 & 10 & 11 & 12\end{array}$

$\begin{array}{lllllllllllll}\text { Recrtation } & 1 & 2 & 3 & 4 & 5 & \text { b } & 7 & 8 & 9 & 10 & 11 & 12\end{array}$

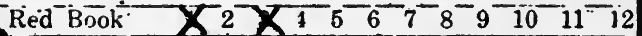

Krev. of Rev. 1 X

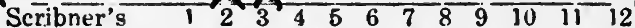

$\begin{array}{lllllllllllll}\text { Smith's } & 1 & 2 & 3 & 4 & 5 & 6 & 7 & \times & 9 & 111 & 11 & 12\end{array}$

:

$\begin{array}{lllllllllllllll}\text { Sunset } & 1 & 2 & 3 & 4 & 5 & 5 & 7 & 8 & 9 & 10 & 11 & 12\end{array}$

$\begin{array}{llllllllllllllll}\text { System } & 1 & 2 & 3 & 4 & 5 & 6 & 7 & 8 & 9 & 10 & 11 & 12\end{array}$

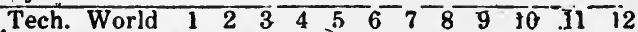

\begin{tabular}{lllllllllll}
\hline World's Work & \\
\hline
\end{tabular} Young's

$\begin{array}{llllllllllll}1 & 2 & 3 & 4 & 5 & 6 & 7 & 8 & 9 & 10 & 11 & 12\end{array}$




\section{PREPARATION OF BOOKS FOR THE SHELVES}

When books arrive, after they have been unpacked, the first thing to do is to check the bill with the order list, to see whether all the books which have been ordered have been received. Next, the bill should be checked with the books which have been received, in order to avoid errors. The date of the bill, initials of the dealer, and cost price of each book should be entered on the left hand margin of the second page after the title page, i. e., $8 / 13 / 16$ Mc. .98 means date of bill, Aug. 13, 1916, name of dealer, McClurg, price of book, 98 cents. Now the book is ready to be prepared for the shelves. This preparation includes the mechanical preparation and technical preparation. Neat mechanical work adds much to the appearance of a book and suggests to the patron care in handling it.

Mechanical preparation-The mechanical preparation includes cutting pages, collating, opening books, stamping, labeling and pasting.

For details in regard to these processes see Essentials in library administration, compiled by Miss L. E. Stearns, p. 41-43. This pamphlet can be purchased from the A. L. A. Publishing Board, 78 E. Washington St., Chicago, price 25 cents.

Technical work-When the books have gone through these mechanical processes, they are ready for the technical work. This includes accessioning, classifying, assigning book numbers, making book cards, shelflisting, cataloging, and sometimes the preparation of a printed list of the books which are in the library.

Accession-The accession record is a record of the books that are added and withdrawn from the library. It shows definitely just how many books are in the library. The author, title, publisher, date, name of dealer or donor, date of bill and cost of each book purchased, are recorded. This record is kept in an accession book, the lines of which are consecutively numbered. Such a book can be purchased from a library supply house. For institutional 
libraries, condensed accession books are best. In these books, simple rules, which can be easily followed, are given for accessioning books. In addition to these, points to be definitely noted are as follows: Give each volume an entry in the accession book. Write the accession number at the bottom of the second page following the title page of the book. Write the number also on the upper right hand corner of the book-pocket. Write it on the book card and shelflist card.

Classification and shelf arrangement. Call numberEvery book in a library except fiction, is entitled to a call number which is used to distinguish it from every other book in the library. This call number is made up of a class number, obtained from a classification table, and a book number assigned from the Cutter-Sanborn Alphabetic order table, to distinguish it from other books in the same class. Example: The call number of Moses Coit Tyler's History of American Literature is

\section{0-Class number \\ T98-Book number}

The call number is to indicate the location of the book on the shelves. It is printed at the top of the second page after the title page, on the upper left hand corner of the book-pocket, on the upper left hand corner of the book card, shelflist card and catalog cards. See samples. It is also printed on the label on the back of the book according to previous direction. The letter $J$ may be used before the call number of juvenile books to distinguish them from adult books.

Classification-In classifying a book, the first thing to do is to determine the content. The librarian will not have time to read every book. He must learn to determine about what a book is written by examining the title page, the table of contents, the chapter headings. Sometimes it is necessary to read the introduction to get the author's point of view, and also to read reviews of a book. It is not safe to classify a book from the title alone, for often the title is misleading. With practice, the librarian will soon learn to judge the contents of the 
book and assign the class number rapidly. Familiarity with the classification table is necessary in assigning the numbers and in finding the books on the shelves.

In most institutional libraries, as in public libraries, books treating of the same subject should be arranged together on the shelves. Such an arrangement is made possible by the use of the Dewey decimal classification system, which with modifications can be adapted to the needs of the various types of institutional libraries.

A copy of the last edition of Dewey Classification can be obtained from the Library Bureau, 6 North Michigan Ave., Chicago. Price $\$ 6.00$. There is an abridged edition, 1912 , which costs $\$ 1.50$ and answers the needs of most institution libraries.

Book numbers-If a distinctive call number is necessary, a book number should be assigned in addition to the class number. This book number not only distinguishes a book from every other book having the same class number, but makes it easier for the librarian to arrange the books by classes in alphabetical order. This number is a combination of the initial of the author's surname, with figures chosen from the Cutter-Sanborn table. These figures in this table are so arranged that books shelved by these author numbers will stand in alphabetical order. Usually in the three figure table the first two numbers are used, leaving the third for a name that might come in between. In assigning the book numbers, the shelflist should be consulted and care should be taken to keep the numbers consistent with those already assigned. If a book has more than one author, the Cutter number is assigned from the name of the first author. In the case of an anonymous book and periodicals, the number is assigned from the first word in the title. If an author has more than one book in the same class, then a lower case letter, the first of the title, is added to the author number.

Example:

Holland, W. j.

Butterfly Book 595

$\mathrm{H} 73 \mathrm{~b}$
Holland, W. J. Moth Book 595 H73m 


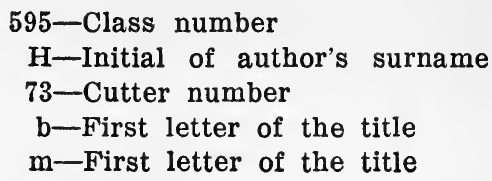

A Cutter-Sanborn three figure alphabetic order table can be ordered from Library Bureau, 6 North Michigan Ave., Chicago. Price $\$ 2.50$.

In some libraries, a simpler arrangement is obtained by omitting the Cutter number altogether, and using the class number with the initial of the surname of the author. Example:

Holland, W. J. Butterfiy Book

595

$\mathrm{H} \mathrm{b}$

The books in a class can be easily arranged in alphabetical order by author. This scheme is advisable when the charging system does not call for a distinguishing call number.

Biography-As a rule, biography is not classified according to the Dewey decimal system. The number 920 is used for all collected biography, and 921 for individual biographies. In collected biography the Cutter number is assigned from the name of the author the same as with other books.

In individual biography, since it is desirable for the biographies of one person to stand together, the Cutter number is assigned from the name of the biographee, or the person about whom the book is written. The initial of the surname of the author is added as a lower case letter, so that different biographies of one person may stand in alphabetical order by author.

\section{Examples:}

Morse, J. T. Abraham Lincoln 921 L73m
Nicolay, J. G. \& Hay, John Abraham Lincoln 921 L73n
Schurz, Carl Abraham Lincoln 921 L73s 
Fiction-Fiction is not classified but is arranged in alphabetical order by author and under author by title. In fiction the accession number may be used as a distinguishing symbol in the charging systẹm.

Catalogs-In institution libraries, as a rule, a shelflist, with explanatory index cards which give the meaning of the class numbers, and an author and title list of fiction will answer the need of a card catalog. In some of the larger libraries, however, where educational schools make a demand upon the library for reference work, a card catalog which shows all the resources of the library is a necessity. This usually takes the form of a dictionary catalog. It should be made by an experienced cataloger and should not be attempted by a person who has had no experience and training in this line of work.

Shelflist-The shelflist is a record kept on cards which are arranged in the same order as the books should stand on the shelves. With non-fiction this is a classified arrangement, and under class, alphabetical. With fiction it is an alphabetical arrangement by author and under author by title. This is a very useful record in taking an inventory of the library.

The shelflist card should show the call number, the accession number, the author, title, number of volumes and number of copies of each book in the library. For forms of sample cards and directions for shelflisting see Stearns' Essentials in library administration, p. 55-57.

Author and title fiction list-Author and title cards are made for fiction and are filed together in one alphabet. This is a convenient record to show what fiction books are in the library. It should be consulted when the book order is being made in order to avoid duplication.

If it is necessary to print a call list from the shelflist, then it is advisable to file the author cards together in alphabetical order and make another alphabetical file from the title cards. Sometimes a charging system requires a consecutive number. In this case, the numbers can be assigned so that the books will stand in alphabetical order.

Author and title cards for juvenile books are similar to 
the cards for adult books except the letter "J" is written in the upper left hand corner to distinguish them from the cards for adult books.

The accession number is written on the back of the author card. If it is desirable to add to this record the author and title cards of non-fiction, the form of the card is the same except that the call number is written in the upper left hand corner, just as on the shelflist card.

Call list-In some libraries, especially in prisons and hospitals for the insane, the general regulations do not permit the inmates to come to the library and select their books from the shelves. When this is the case, it is necessary to have a printed call list from which the books can be selected. This call list can be printed direct from the shelflist. The non-fiction will have a subject arrangement, and the fiction alphabetical by author. Since the inmates do not have a chance to see the books, it is advisable to have under each author entry, a short descriptive note, telling something of the content of the book, or giving a brief outline of the story. These notes or annotations have been found invaluable and do much to raise the standard of reading. Books will be chosen that would otherwise be left on the shelves if the title were the only clew to the nature of the book. The work of printing is usually done on the institutional press, therefore it can be kept up to date without any great expense. However, some institutions have found the printed list impractical, because of the withdrawal of books and the purchase of new books at frequent intervals. The librarian and teachers of the Indiana Boys' School, Plainfield, have worked out a splendid substitute for the printed catalog. Following is their description of it:

"We have substituted a card system to take the place of our printed catalog, and we find that this system meets the problem with which we have to contend much better than the old system.

"A card is made for each of the three thousand books in our library. Reference books are excepted. On this 
card is shown the call number, name of author, title, grades in which the book may be read to advantage, and a few short remarks as to the contents of the book.

"As the boys of the institution are divided into fifteen companies, we have divided the cards into fifteen groups, putting each group into a double-tray box made for the purpose. One of these boxes is put in each company home, and the boys of that company choose their books from the cards in that box for a period of a few weeks, when the boxes are changed from one company to another.

"Each company has a monitor whose duty it is to make out the list of books, as selected by the boys in his company. As boys select their books, the cards are turned in the box so that no two boys select the same book.

"The advantages of this system are very evident. Following are some that are especially important:

“(1) No two requests are made for a book, thus substitution by the librarian, nearly always unsatisfactory, has been eliminated.

"(2) Having a short synopsis of the book or a few catchy remarks concerning its contents, will cause some of our best books to be called for and read, whereas, heretofore, they have been passed by because our catalogs contained only the title.

“(3) When new books are received, they can be put into the hands of our boys at once without waiting for a supplement to be printed for the catalogs. When books are withdrawn, the cards can easily be removed from the boxes.

"Boys are to select books from catalog cards, the monitor writing on the library list, the name, number in full, and the grade of book selected opposite the name of the boy making the selection. The catalog card should be turned as soon as the above is copied in order that two or more boys cannot choose the same book." 


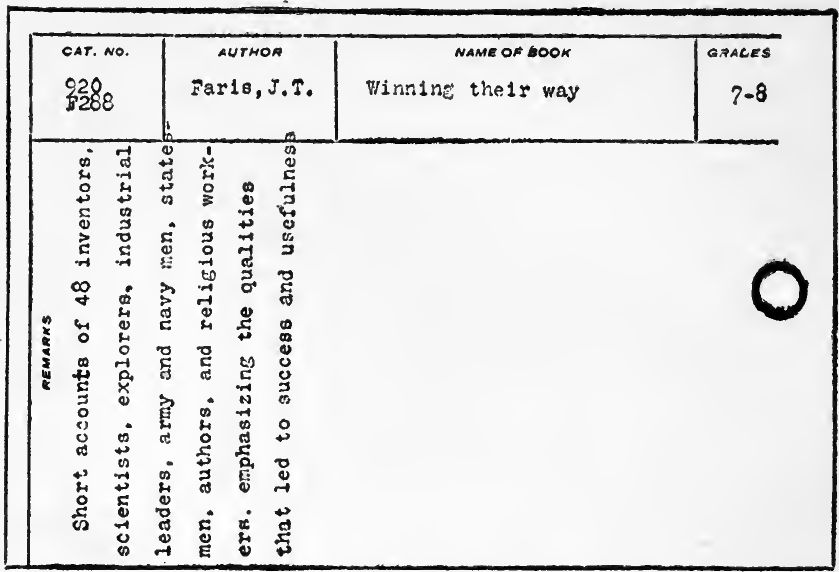

SAMPLE CATALOG CARD USED AT THE INDIANA BOYS' SCHOOL. (Size $61 / 2 \times 4 \frac{1}{2}$ in.)

A rod runs through the center of the double tray of the box in which the cards are filed. The card is fastened on this rod, and is turned to the vacant tray when a book is selected.

Loan System-Institutions vary so in character, and local rules and regulations play such an important part in daily routine, that it is difficult to devise a uniform scheme for circulating books. A good charging system in an institution should show what books are out of the library, who has them and when they are due. It should also show what classes of books are circulated, and in some institutions it is interesting to know the character of the reading of each inmate. Librarians are generally agreed that these questions can be answered better by the use of a card charging system than a ledger system. In institutions where the inmate can come to the library and select his books, a system that is employed in many public libraries can be adopted with modifications. In this system book cards, book-pockets, readers' cards, registration book are necessary. 
Book cards-Each book should have a card to represent it when it ts out of the library. This card should show what book is out, who has it and when it is due. The call number of the book, the author, title and accession number are written on the card. The card is placed in the pocket which is pasted on the inside of the back cover of the book. On this pocket the call number is written on the upper left hand corner, and the accession on the upper right hand corner, the same as on the book card. By matching these numbers the librarian can be sure that she has the right card in the right pocket.

SAMPLE BOOK CARDS

Adult. Non-fiction

Adult. Fiction
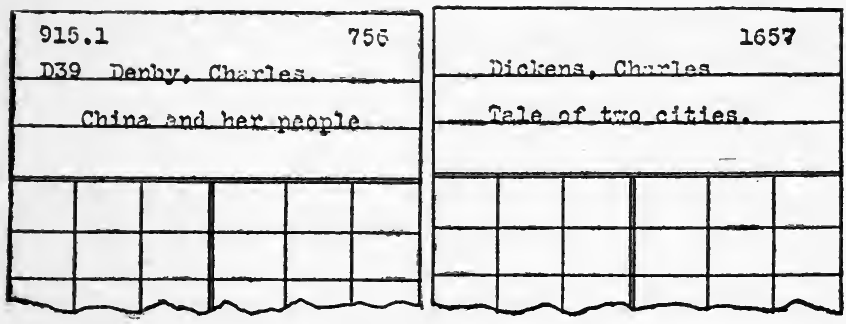

Cards for juvenile books are similar to these, except the letter $\mathbf{J}$ is placed before the class number on the non-fiction card, and on the upper left hand corner of the fiction card.

Form for a book card, in an institution where reader's cards are not used. Size of card $3 \times 51 / 4$.

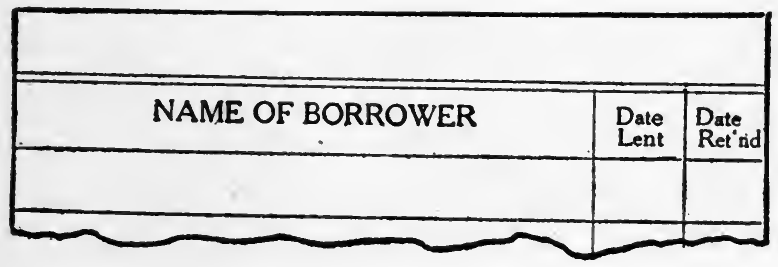


Readers' cards-Each reader is given a card on which is written his name and registration number. The cards are kept filed in the library in alphabetical order when not in use.

\section{SAMPLE READER'S CARD}
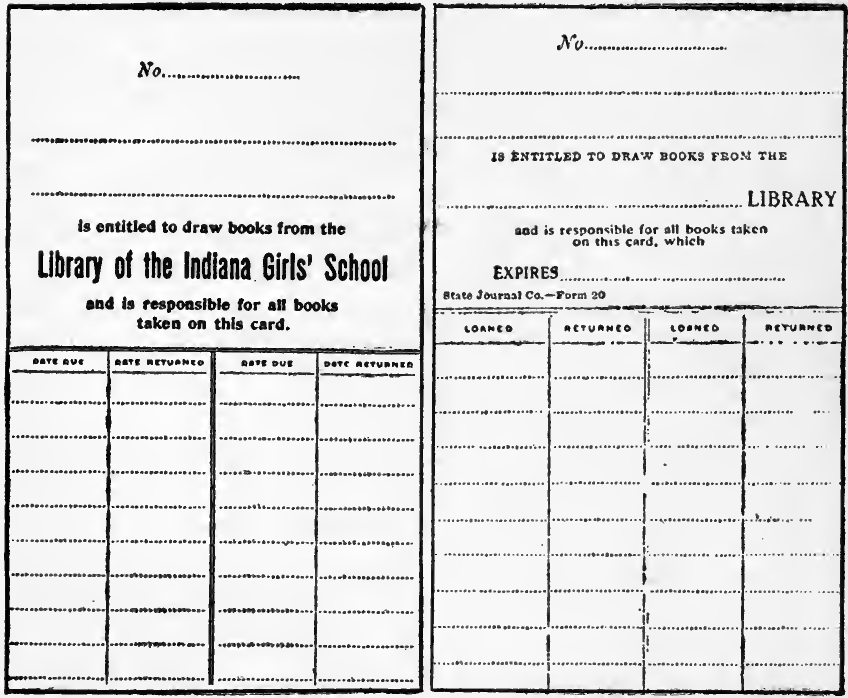

A regular registration book can be purchased from a library supply house or a blank book or record book can be used. Each line is numbered consecutively and a number assigned for the name that is written opposite to it.

Lending a book-Take book card from the book-pocket in the book. Write borrower's number and stamp date loaned opposite. Stamp the same date on reader's card. Flle book card in tray back of date guide and put borrower's card in book-pocket. In the charging tray the fiction book cards should be filed in alphabetical order by author. The non-fiction cards should be arranged by class numbers. If it is desirable to keep track of the 
borrower's reading, the call number of the book can be written on the reader's card.

Sometimes, librarians prefer to stamp the date due. Readers are usually allowed to keep books two weeks, but this is regulated by the local rules and regulations.

Returning a book-Stamp date of return on reader's card. Take book card from tray and return to bookpocket. Place book on shelf.

This charging system is well adapted to the needs of educational and charitable institutions. Sometimes it is simpler to dispense with the registration number and the reader's card. Then a date-slip is pasted on the page opposite the book-pocket. On the slip, the date the book is loaned is stamped. The borrower's name is written on the book card and the date loaned is stamped opposite. In some institutions, the name of the borrower is all that is necessary to write on the card. Then there is no

(Size $3 \times 5$ )

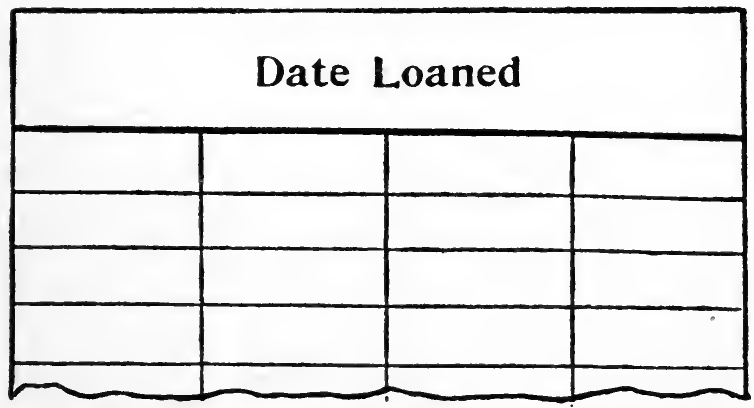

need of the date-slip. In prisons and hospitals for the insane, where it is not practical for the borrowers to go to the library to select their books, modifications of this system must be devised.

Prisons and reformatories-Each prisoner is given a printed list of the books in the library, from which to choose books. Annotations will add much to this list as a guide for selection. $\mathrm{He}$ is also given a request slip, 
upon which is written his name, cell number and registration number. Upon this slip he writes each week the number, author, and title of the books which he wishes to read, putting them down in the order of his preference. These lists are sent to the librarian and one book from each list is sent to the prisoner. The prisoner's name or number is written on the book card and the cards are filed in the manner already indicated.

Usually each company, patrol, or family has a certain day each week on which to get library books. If this is the case, it will be more convenient to file the readers' cards in alphabetical order by company or patrol, if readers' cards are used.

SAMPLE REQUEST SLIPS
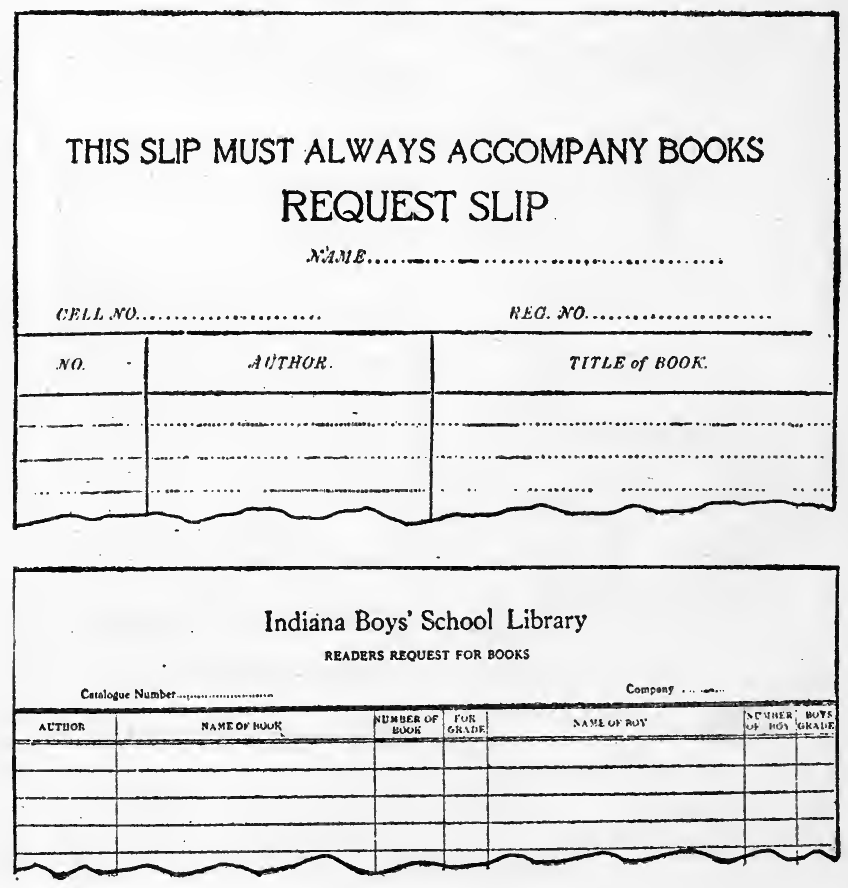
MANUAL FOR INSTITUTION LIBRARIES

29

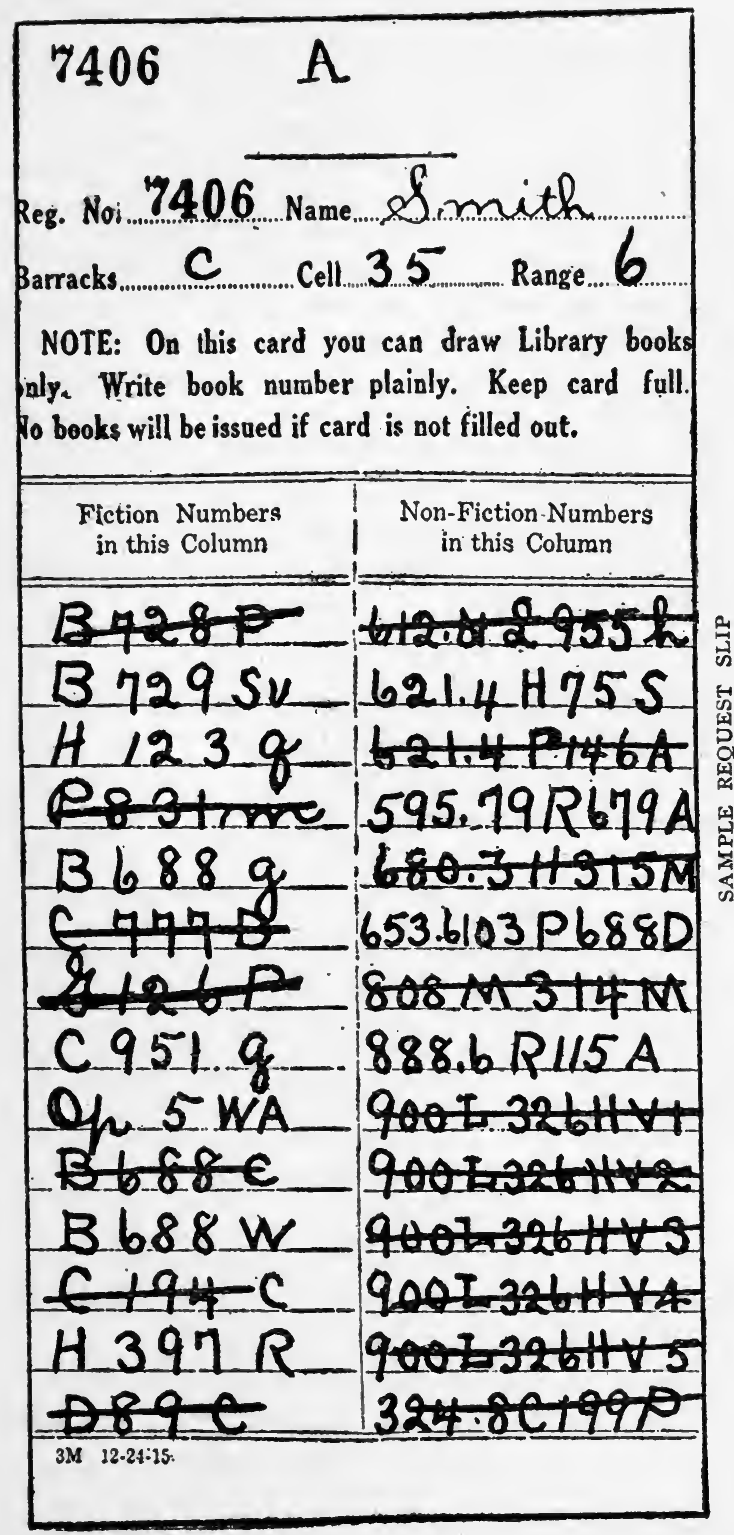


Hospitals for the insane-In a hospital for the insane, it is better to have one central library than to have libraries in each ward. Once a month or twice a month, as is needed, collections of books are made up at the main library and sent to each ward. If it is desirable to keep track of the circulation of the books in the wards two book cards are made for each book, a white one for individual book circulation and a colored one to show what books are sent to each ward.

When the collections of books are made up the colored cards are withdrawn from the books and filed in the library behind a guide with the name of the ward to which the books are charged. The white cards are left in the books to be used for individual loans on the ward.

The white cards can also be used in the books for institutional employees.

\section{SAMPLE BOOK CARDS}

Book card for individual book circulation (white).

Book card for ward circulation (colored).
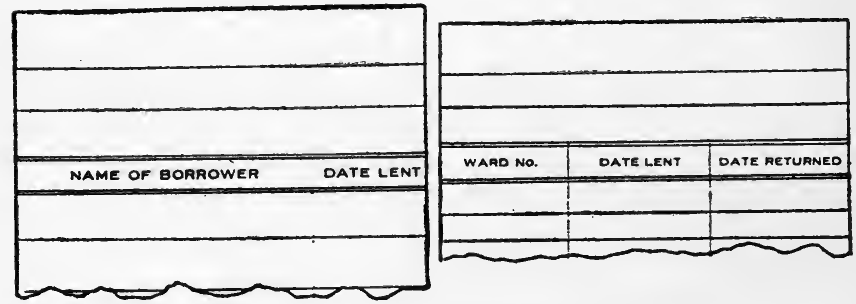

LIST OF SUPPLIES FOR 1000 VOLUMES

Library Supply Firms

Democrat Printing Company, Madison, Wis.

Gaylord Brothers, Syracuse, N. Y.

Library Bureau, 316 Broadway, New York City, N. Y., 43 Federal St., Boston, 6 N. Michigan Ave., Chicago. 
American Library Association Publishing Board, 78 E. Washington St., Chicago.

The following list of supplies has been made up from the catalogs of the above firms. The latest catalogs of these firms should be kept on file at each institution library. If there is a printing press in connection with the institution, many library supplies can be printed at a minimum cost.

Classification:

Order from the Library Bureau

1 Abridged Dewey decimal classification and relative index. No. 1002 cloth. Price.......\$1.50

1 Cutter-Sanborn three figure alphabetic order table.

No. 1037. Price .................... 2.50

\section{Shelflist:}

If cards are to be written long-hand, order ruled cards.

If a typewriter is to be used, order plain cards.

1,000 catalog cards, standard size $7.5 \times 12.5 \mathrm{~cm}$., (approximately $3 \times 5$ in.).

Democrat Printing Co., no. 2 (second weight) Ruled.

Price ............................\$2.50

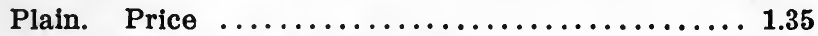

Gaylord Bros. L. No. 301 Ruled.............. 2.15

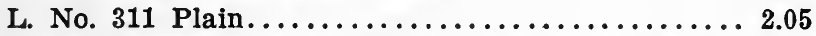

Library Bureau. No. 33012 Library ruling, white,

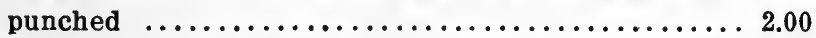

No. 33015 Typewriter, punched .................. 2.00 100 Plain standard card catalog guides. (Thirds buff)

Democrat Printing Co. .................. .50

Gaylord Bros. ........................

Library Bureau ........................ $\quad .50$

1 Four-tray cabinet. Library Bureau. No. 2314..... 9.00

If Author and Title list is to be made order 2,000 extra catalog cards.

\section{Catalog:}

Catalog cards must be of the best grade linen stock, for this is a permanent record often consulted.

3,000 catalog cards. Standard size $7.5 \times 12.5 \mathrm{~cm}$., (approximately $3 \times 5$ in.). 
Democrat Printing Co. No. 1. (Heavy weight) Ruled.

Price ............................\$9.00

Plain ............................. 4.50

Gaylord Bros. M301 Ruled .............. 8.25

M311 Plain ............................ 75

Library Bureau. No. 33032 Library ruling white punched ........................... 9.00

No. 33030 Plain white punched............ 9.00 300 standard card catalog guides (Thirds buff)

Democrat Printing Co..................\$1.50

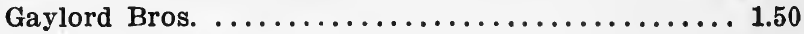

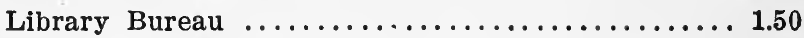

Cataloging rules:

Cataloging rules on cards, being simplified rules adopted for use in the Wisconsin Library School, compiled by Helen Turvill, instructor in cataloging. There are over 500 rules and sample cards, covering the most necessary points in library cataloging. The rules are printed on cards of catalog size to be arranged alphabetically by headings, making every rule of the easlest possible access. Democrat Printing Co.....................\$2.50

Cataloging rules on cards. Printed guides.

Guide cards, printed with subject headings on onefifth cut manila guides, ready for filing, will be furnished with this set for 50 cents additional.

Hitchler, Theresa. Cataloging for small libraries, revised edition 1915. A. L. A. Publishing Board.....\$1.25 Subject headings:

A. L. A. Subject headings for use in dictionary catalogs, edited by Mary J. Briggs. A. L. A. Publishing Board .............................. \$2.50

Subject headings for use in dictionary catalog of juvenile books. Compiled by Margaret Mann. A. L. A. Publishing Board ..................... 1.50

\section{Cabinet:}

If catalog is to be made in addition to shelflist, order six-tray cabinet. Library Bureau No. 2316.....\$12.00 


\section{Accession:}

2,000 line condensed accession book.

Democrat Printing Co.................\$3.00

Gaylord Bros. ........................... 3.00

Library Bureau .............................. 3.00

\section{Loan System:}

Registration book, or Borrower's register.

A well-bound 2,000 line record will answer this purpose. In many institutions a registration book is unnecessary. Following are the prices of regular registration books, 25 lines to the page and half numbered at the left margin.

Democrat Printing Co. No. 2.............\$3.00

Gaylord Bros. No. 55................... 2.20

Library Bureau No. $1150 \ldots \ldots \ldots \ldots \ldots \ldots \ldots \ldots 2.00$

Borrowers' Cards:

The number to be ordered depends upon the number of inmates in the institution. In many institutions, borrowers' cards are unnecessary. If the inmate comes to the library to select books for himself, then this card is quite a convenience. In some institutions it is better to have this card planned especially for the institution. In others, stock cards answer the purpose very well.

Democrat Printing Co. Stock cards......\$2.80 per 1,000 Gaylord Bros. Printed with name of library 3.50 per 1,000 Library Bureau. 1127.3 Printed with name

of library ........................ 1,000

Unprinted ................... 2.50 per 1,000

\section{Date-slips:}

1,000 Fourteen-day or seven-day slips. Plain slips $3 \times 5$ in. can be used.

Democrat Printing Co..................\$1.50

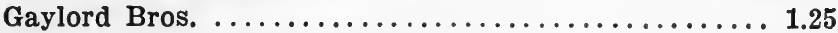

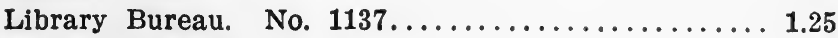

\section{Book-pockets:}

1,000 Book-pockets.

Democrat Printing Co. Open end pockets, unprinted.\$1.75

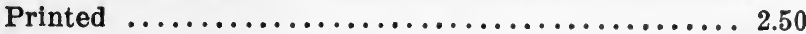


Gaylord Bros. Style A. With three gummed edges.

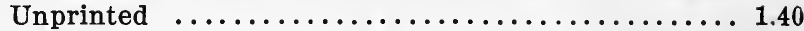

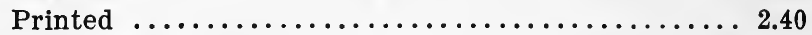

Style C. Strip made of heavy manila. Will hold all sizes of cards. Unprinted................. .85

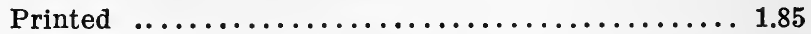
Style F. Open end folded and sealed. Unprinted 3.00 Printed .............................. 4.00

Library Bureau. Open end. No. 11672. Unprinted.. 1.75

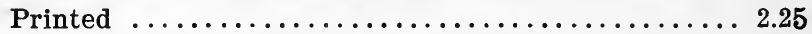

Manila book-pocket strip. Unprinted.......... $\quad \mathbf{7 5}$

Printed ............................. 2.50

\section{Charging tray:}

When books are lent, the book cards should be filed in this tray. If double tray is purchased there is also a space to file borrowers' cards.

Democrat Printing Co. Single oak tray with sliding block, capacity for 700 cards and guides. Withoutcover .............................\$0.55

With one set vertical date guides $\ldots \ldots \ldots \ldots \ldots \ldots . .90$ Double tray same as above, accommodating twice as many cards. Without cover and with one set of

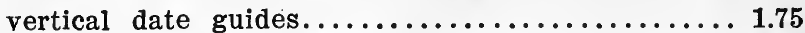

Without cover or guides................... 1.40

With cover and one set of guides.............2.50

Gaylord Bros. No. 50b. Single oak tray, no top; capacity 1,000 No. 35 charging cards. Complete with one

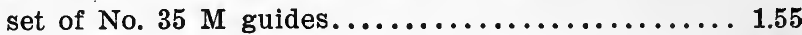

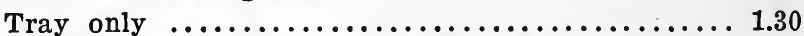

No. 40. Cloth covered charging tray, capacity 1,000 cards and guides. No top. Complete with one set of No. 35 M. guides .....................1.15

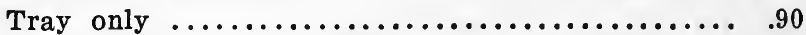

Library Bureau. No. 1200 Antique oak tray with cover, two compartments; capacity 2,000 of No. 1147 cards. Complete with follower blocks, date guides (11851). Tray with guides ........................... 3.75

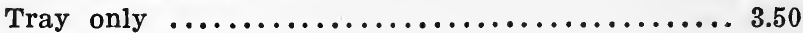


No. 1203 Antique oak tray, no cover, one compartment, capacity 1,000 (1145) cards. Complete as above. Tray with guides $\ldots \ldots \ldots \ldots \ldots \ldots \ldots . . .6 .75$

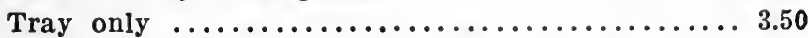
No. 12031 Antique oak tray, light construction, no cover, one compartment, 800 (1145) cards. With

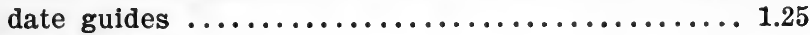

Date guides:

Democrat Printing Co., 1-31...........\$0.35 per set

Heavy press board with celluloid tips 1-31.. .80 per set Gaylord Bros. Guides for No. 35 charging cards,

$1-31$.................................. 30 per set

$1-31$ celluloid $\ldots \ldots \ldots \ldots \ldots \ldots \ldots \ldots \ldots . .70$ per set

Library Bureau. No. 11851. 1-31..........30 per set

1-31 celluloid .....................70 per set

Pencil dating outfits:

An outfit consists of a pencil date holder, a set of solid rubber dates and a stamp pad.

Democrat Printing Co...................\$0.75

Gaylord Bros. No. 801 or 804 . Without ink pad.... .60 Library Bureau. No. 1302 Complete............. .75

Request slips and printed lists can be made at the institution, and also a number of these supplies used in the loan system.

\section{Miscellaneous:}

1,000 gummed labels.

Democrat Printing Co., A. 44 round, box of $1,000 \ldots \$ 0.25$

Gaylord Bros. A 44 round, box of $1,000 \ldots \ldots \ldots \ldots .30$

Library Bureau. No. 1456 round, box of $1,000 \ldots \ldots .30$

Periodical record cards (monthly).

Democrat Printing Co. $100 \ldots \ldots \ldots \ldots \ldots \ldots \ldots . \ldots \ldots$

Gaylord Bros. $100 \ldots \ldots \ldots \ldots \ldots \ldots \ldots \ldots \ldots . .60 \ldots$

Library Bureau. 100 No. $1105 \ldots \ldots \ldots \ldots \ldots \ldots . .60$

Book supports.

Count one support for each shelf.

Democrat Printing Co., per $100 \ldots \ldots \ldots \ldots \ldots \ldots \$ 7.50$

Gaylord Bros., Style A., per $100, \$ 7.00$; per doz..... 1.60 
Library Bureau, No. 1340, per $100 \ldots \ldots \ldots \ldots \ldots .6 .60$

Lots of 10 or more at rate of ............ .90

Orders from local dealers.

1 bottle Higgins' American India Ink..........\$0.25

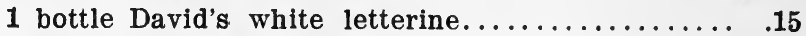

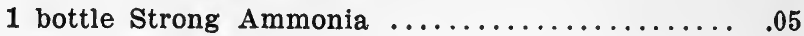

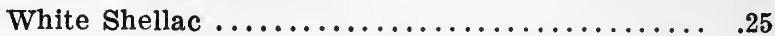

2 small camel's-hair brushes $(1 / 4$ inch $) \ldots \ldots \ldots \ldots . .10$

1 Rubber stamp, name of the library for mark of ownership, and pad ....................65

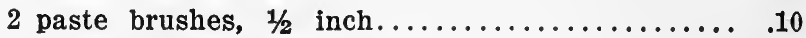

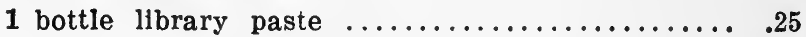

1 bone or steel paper-knife.................25

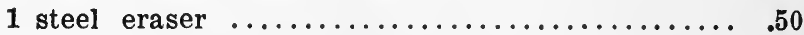

Carter's Koal black ink, pint bottle.......... .35

Carter's Vermilion ink, small bottle.......... .10

Order from the American Library Association, Publishing Board, $78 \mathrm{E}$. Washington St., Chicago, Essentials in library administration, compiled by Miss L. E. Stearns, 2nd ed., 1912, price $\$ 0.25$.

Mending and repair of books, compiled by Margaret Wright Brown. Third edition revised by Gertrude Stiles. 1916 , price $\$ 0.15$.

\section{BOOK MENDING SUPPLIES}

Tools:

Binders' knife or an ordinary paring knife purchased at any hardware store.

Scissors, narrow five or six inch blade.

Purchased at any dry-goods or hardware store.

Bone folder. Purchased at any stationers. 15 to $30 \mathrm{c}$. Needles. Large size needle or darning needles.

Thread. For sewing in loose sections in loose back books: Binder's thread, 10c a skein. Barbour's linen thread No. 30. Purchased at any dry-goods store, 10c a spool.

1 sponge cup.

112 inch rule. Purchased at any stationers. 
1 Glue pot. 1 Alcohol lamp. Purchased at any hardware store.

Brushes: 1 long handled $1 / 2$ inch round brush for paste. 10c. 2 inch soft brushes for shellac. 10c.

Parafin paper. For putting between leaves to keep paste from sticking them together. May be bought from any stationer or department store. 5c a roll.

Cheesecloth. Cut in squares 12 by 12 in. for wiping fingers. 5c a yard.

Press. A regular letter press will answer the purpose. Purchased at any stationers.

Materlal used in mending and cleaning books:

Lawn. For putting in two or more loose leaves in a tight-back book. Cut in strips $11 / 4$ inches wide. Stitch together two or three strips and keep in a box so as to have them handy. At any dry goods store: 121/2c a yard.

Success Binder. Also used for fastening loosened leaves. Put up in rolls five yards long. Furnished in strips $1,11 / 2$ and 2 inches wide. Gaylord Bros. 25c per roll.

Super. A loosely woven cloth, used in re-casing books. May be purchased from any binder. A light weight outing flannel, cheese cloth or lawn may also be used for this purpose.

Double-stitched binder. For refastening covers on books which are either partially or entirely broken away from the contents. Put up in varying widths. Gaylord Bros., 30 c a roll.

Onion skin. For mending torn pages. Glazed, $17 \times 22$ in., ungummed, 2c a sheet. Unglazed, $17 \times 22$ in., ungummed, $2 \mathrm{c}$ a sheet. Gummed, $10 \times 16$ inches, 16 strips to package, 15c. Democrat Printing Co. Gaylord Bros.

Paper cambric or book muslin. For mending joints. Purchased at any dry-goods store. $8 \mathrm{c}$ to $13 \mathrm{c}$ per yard.

Adhesive cloth. Also used for mending joints and reinforcing broken sections. Regular size package contains 16 strips, each $1 \times 9$ in. Gaylord Bros. 20c.

Art vellum in assorted colors. For covering soiled books. Cut in 1/3 yard strips. May be purchased from any book- 
binder or from Democrat Printing Co., and Gaylord Bros. 30c a yard.

Silk finish adhesive cloth. Also used for mending and replacing the cloth on the backs of books. Put up in rolls of varying widths and lengths. 3 rolls, 65c. Gaylord Bros.

Sheets of bond paper. For mending leaves, where part of the page is missing. Purchased at any stationers. 1c a sheet.

End sheets. Gray granite paper. 20x25 in. Democrat Printing Co. 6c a sheet.

Art gum. Used in cleaning soiled covers and pages. Purchased at any stationers. 10c.

Pumice. Powdered pumice for cleaning soiled pages and covers. Any drug store.

Shellac. Best white shellac for varnishing backs and sides of books. Any drug store. 50c a pint.

Inks. David's white letterine for lettering books, 15c a bottle. Higgins' American India ink for lettering light covers. 25c a bottle. Any stationers.

Paste. Library and drawing board paste, manufactured by Chas. M. Higgins \& Co., Brooklyn, N. Y. This paste has been found to be excellent for mending. It can be bought in large or small quantities and keeps well. $14 \mathrm{oz}$. jar, 50c.

It is cheaper to make paste than to buy it. For recipe for flour paste see Brown's Mending and repair of books, 3rd ed., p. 13; Stearns' Essentials in library administration, p. 89.

Glue. Used only for backing and covering books. Do not use glue on books which are to be rebound.

Dennison's liquid glue, diluted with vinegar. $40 \mathrm{c}$ a small can; 80c a large can. Purchased at any stationers.

Flexible glue. Gaylord Bros. $\$ 1.15$ per quart.

Sticktite flexible glue (white). Queen City Paper Co., Cincinnati, O. 5 lbs., $\$ 0.75$.

Flexible glue has been found very satisfactory in rebacking books that are not to be rebound. 


$$
\text { · }
$$

$$
\text { - }
$$





\section{UNIVERSITY OF CALIFORNIA LIBRARY}

\section{BERKELEY}

Return to desk from which borrowed.

This book is DUE on the last date stamped below.

DEG 21953

EI SD:

LD 21-100m-7,'52 (A2528s16) 476 
GAYLORD BROS., INC.

Manufacturers

Syracuse, N. Y.

Stockton, Calif.

THE UNIVERSITY OF CALIFORNIA LIBRARY 


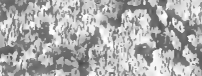

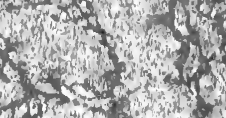

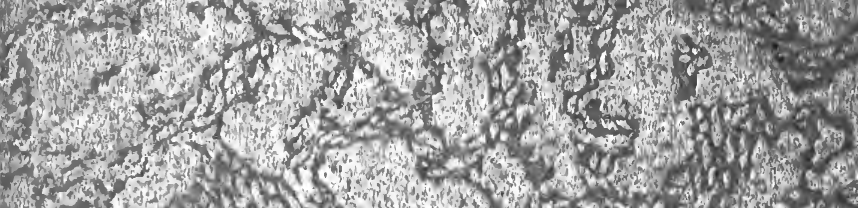

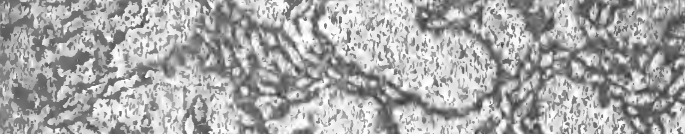

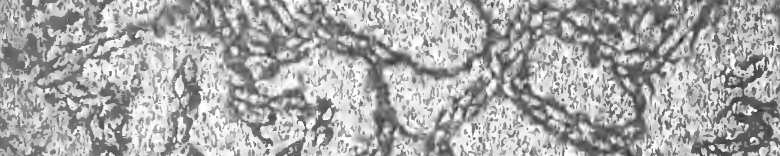

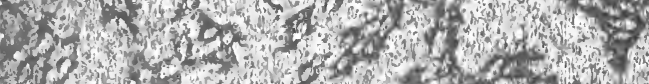

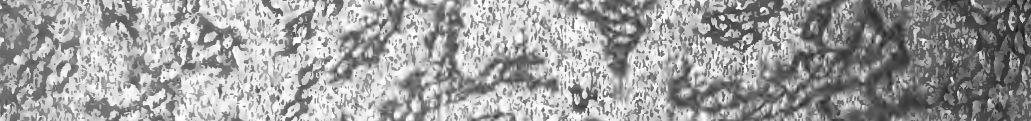

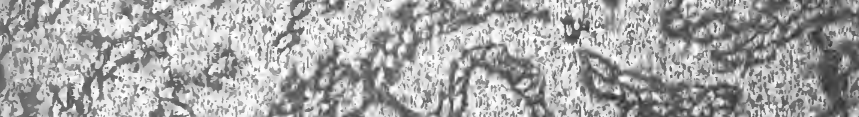

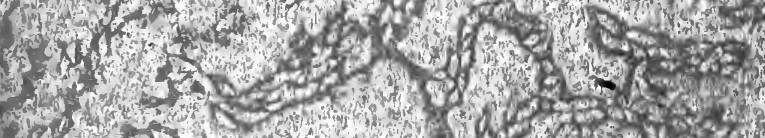

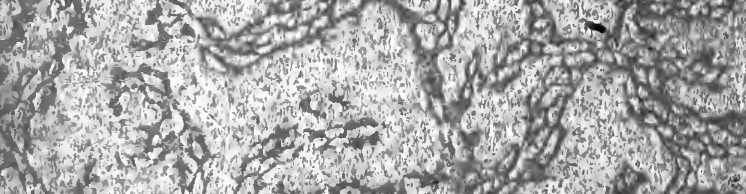

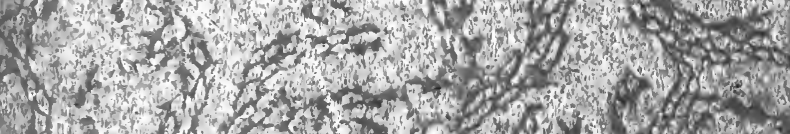

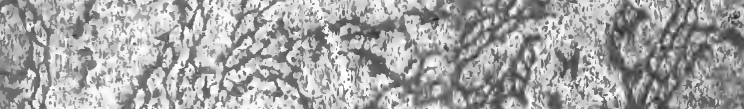

10.7 .

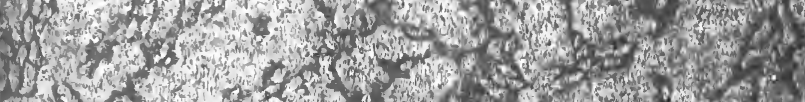

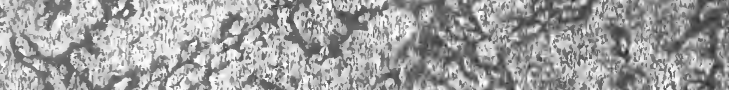

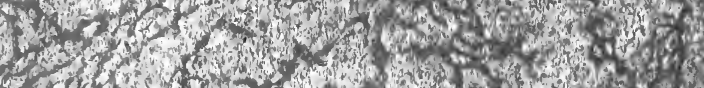

Cof

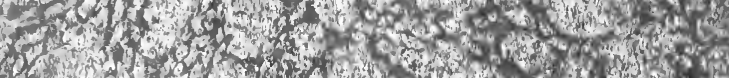

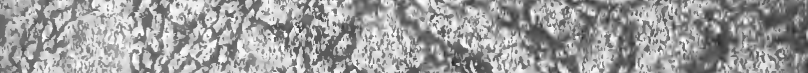

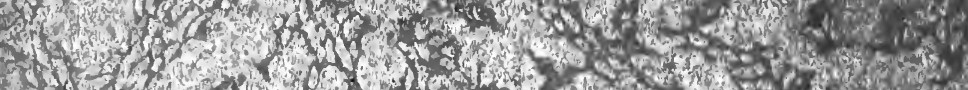

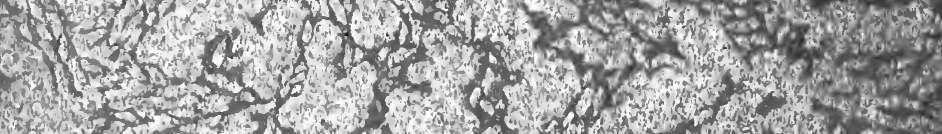

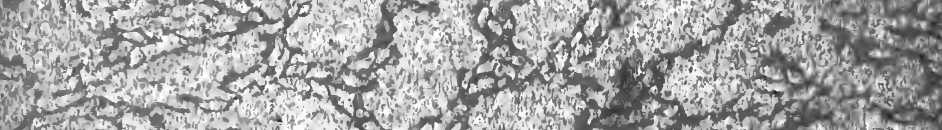

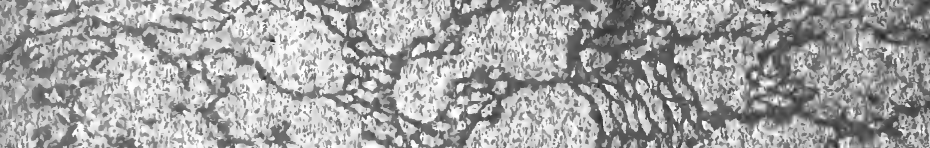

10.

(1) 132

(2)

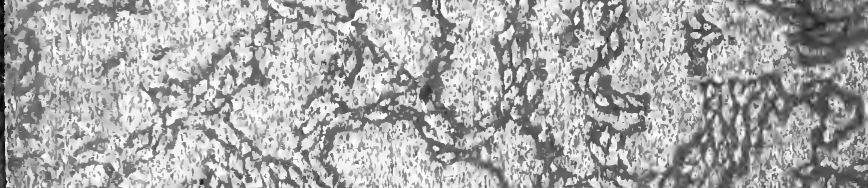

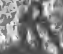

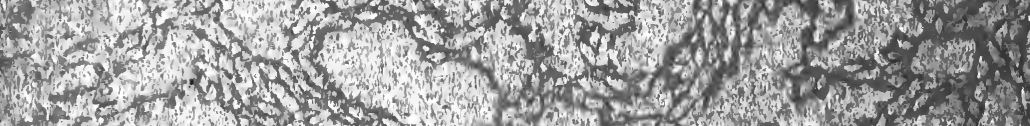

